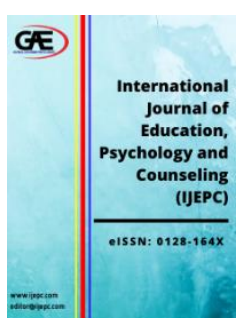

International Journal of Education, Psychology and Counselling (IJEPC)

Journal Website: http://ijepc.com/ eISSN: 0128-164X

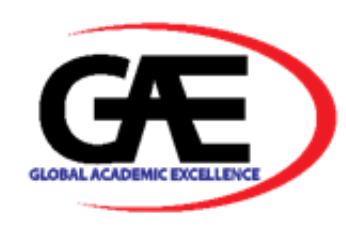

\title{
EXPECTATIONS AND REALITY OF LEARNER AUTONOMY AND COMMUNICATIVE COMPETENCE IN PAKISTANI HIGHER EDUCATION INSTITUTIONS: A REVIEW
}

\author{
Choudhry Shahid ${ }^{1}$, Prof. Dr Ong Eng Tek ${ }^{2}$, Prof Madya Wong Kung Teck ${ }^{3}$, Dr. Asma Perveen ${ }^{4}$
}

$1 \quad$ Faculty of Human Development, University Pendidikan Sultan Idris (UPSI)

Email: ch.shahid70@gmail.com

2 Faculty of Human Development, University Pendidikan Sultan Idris (UPSI)

Email: ong.engtek@fpm.upsi.edu.my

3 Faculty of Human Development, University Pendidikan Sultan Idris (UPSI)

Email: thomas@fpm.upsi.edu.my

$4 \quad$ Faculty of Human Development, University Pendidikan Sultan Idris (UPSI)

Email: asmaperveen@fpm.upsi.edu.my

\section{Article Info:}

\section{Article history:}

Received date:26.12.2019

Revised date: 05.01.2020

Accepted date: 06.01 .2020

Published date: 15.03 .2020

\section{To cite this document:}

Shahid, C., Ong, E. T., Wong, K. T., \& Perveen, A. (2020). Expectation and Reality of Learner Autonomy and Communicative Competence in Pakistan Higher Education Institutions: A Review. International Journal of Education, Psychology and Counseling, 5 (34), 91-101.

DOI: $10.35631 /$ IJEPC.534007.

\begin{abstract}
:
The primary aim of this study is to analyse the main factors affecting the learner autonomy and communicative competence of the EFL learners at higher education level in Pakistan. Nowadays, the English language is considered a language of education, business, and research, moreover, English is a medium of instruction in higher education institutions in Pakistan and communication ability and autonomy are regarded highly important skills for the students' academic success and professional development in the university context. This study has used the literature review and situational analysis approach in order to explore the teaching and learning of the English language at the tertiary level in Pakistan. This study will discuss the present situation of English Language teaching in Pakistan, and the main challenges hindering the skill development of the students. This study has recommendations for the policymakers, teachers, trainers, and students struggling to develop communicative competence and learner autonomy at higher education level in Pakistan. The finding of the study indicates that gap in skill development, low proficiency, improper evaluation, and problematic pedagogy are the main factors affecting skill development in the Pakistani EFL context. Students' skills can be promoted incompetence and autonomy areas by providing them with interpersonal and physical space in learning the target language.
\end{abstract}

Keywords:

Communicative Competence, Communicative Language Teaching, Learner

Autonomy, Pedagogical Issues 


\section{Introduction}

English language has become a lingua franca, and the students' competence in the English language learning decides the way they live and move around the world. Language is a social need and through language learners create meanings and understand their experiences and the world around them. English language is set of different competencies that includes; grammar knowledge, social knowledge, discourse and strategic knowledge. Hymes (1971) urged that teaching a language is not teaching only grammar rules but how to use the language effectively in various contexts is more important. This idea was different from the Chomsky's linguistic competence that focuses language definition based on grammatical competence only. According to Hymes language is a social behaviour and this idea is in accordance with Halliday's (1973) "meaning potential" view of language learning, and many other language scholars have also validated this communicative competence stance of Hymes (Bachman \& Palmer 1981, Canale \& Swain 1980, Harley \& Swain 1984).

There is a key relationship of learner autonomy and communicative competence (Benson, 2011), whereas autonomous learners are more capable (Littlewoods, 1999; Oxford, 2008) and achieve high academic success and have more career opportunities (Boud, 1988). According to the Organisation for Economic Cooperation and Development (OECD) report (2013), the regular university education does not ensure the communication skills, self-directedness and critical thinking. The student shall have to learn "how to learn" (Little, 1996). Communicative competence and learner autonomy are included in the category of lifelong skills, and these should be developed along with other skills such as, technological expertise, numeracy, literacy, planning, self-confidence, leadership and team building skills (Knapper, 1988; OECD, 2007; OECD, 2016). Learner Autonomy makes a learner responsible, reflective towards planning, find strengths and weakness. Autonomy is an ability to control learning, a capacity for independence, decision making and detachment. Communicative competence is an ability to know how, where and what to speak effectively. According to Littlewood (1999): ...if we define autonomy in educational terms as involving students' capacity to use their learning independently of teachers, then autonomy would appear to be an incontrovertible goal for learners everywhere since it is obvious that no students, anywhere, will have their teachers to accompany them throughout life (p. 73).

The students of undergraduate programmes in colleges and universities put efforts to develop their communicative competence and they use variety of learning strategies to achieve academic success and adjust to their language learning needs. The universities students are grown up and considered have ability to take charge of their learning and this makes easy for the teachers to help them to be self-directed. Teachers' instructional strategies and communicative competence level can make the students proficient and responsible for their learning during the process of learning.

This study will examine the English language teaching and learning in the higher education level in Pakistan in order to explore the factors affecting the students' communicative ability and autonomy.

\section{Literature Review}

No learning can be successful without involving the learners in the learning process, and their beliefs and hopes should be considered by the teachers while planning for teaching and learning language and for all this to happen a need analysis is the prerequisite. Once learners' needs are identified then with proper implementation of communicative approach in the classroom with form-focused instructions and contextualization of the activities with everyday life learning 
objective can be achieved easily. This way analysis will be helpful in making learners autonomous and develop their communicative competence. Communicative competence and autonomy are the important skills in second language learning and help the learners in their whole life and after the industrial revolution and globalization, these are regarded among the prime skills in the corporate world (Benson, 2011). The ever-growing popularity of English language in the global context has made communication skills a prerequisite to getting higher education, start a business or to work as a professional. Most employers seek graduates who are good team players, independent, decision makers, adaptable, confident and have strong communication skills (Suartra et al., 2017).

Researcher on learner autonomy in Pakistan; Akhtar, (2016); Mahmood, (2016); Yasmin and Sohail (2018); have concluded that the concept of learner autonomy is new to the teachers and the students in Pakistan but of high significance to prepare them to become self-reliant and responsible for their learning. There is a need to support the teachers and conduct more research in this area to explore and to pave the path of this concept. Unfortunately, Schools, colleges and universities in Pakistan are teaching language as a subject, and more efforts are needed to develop the language competence of the students appropriately. There is a need to find a way to overcome the hurdles and deliver the students what they need in language learning to compete and succeed academically and professionally. An innovative strategy attracts the students and engages them in learning, and it all depends on the teachers how carefully they plan their teaching activities. Students at higher education level are considered great capital for their country and there is crucial role of university education in developing the society and contributing to the economy. Teachers and their good teaching practices play an important part in the higher education level. Sayed (2010) argues that only professionally trained teachers have the potential to use innovative methods and new techniques to impart lifelong education. The students' motivation and involvement in the class can develop a better teaching strategy.

A teacher who has learnt autonomously encourages it by taking the role of a facilitator and as a dispenser of knowledge. Teachers' knowledge and skills in language teaching strategies are the keys to provide a model to develop learner autonomy (Çakici, D. 2015). The concept of learner autonomy with language teachers in Pakistan is needed to be firmly established (Yasmin, M. \& Sohail, A. 2018). There is a need to prepare learners how to learn, aware them with new learning strategies and change their traditional perceptions about language learning (Çakici, 2015), and to accomplish this task teacher should have an expert level competence in English language teaching to motivate the learners in the classrooms (Rawan, 2016). Mahmood (2016) states that Pakistani teachers themselves need awareness related to learner autonomy in order to better impart it to their students.

In Pakistani society, English is regarded as a symbol of power and success and students in the English as a medium of instruction at higher education need strong communication skills and self-directedness (Dar \& Khan, 2015; Sadia, Bashir \& Zafar, 2018; Yasmin \& Sohail, 2018). Higher education and employability success largely depend on the students' communicative competence and autonomy (Saeed \& Rashidi, 2017; Abbasi, 2018) and there is a positive correlation between language competence, autonomy and motivation of the students (Yasmin $\&$ Sohail, 2018). The above review of the literature shows the significance of learner autonomy and communicative competence at tertiary level and of these skill developments to bridge the gap. 


\section{The Problem Statement}

Research about learner autonomy and language competence can help teachers and students to translate theory into practice in the classroom (Yasmin \& Sohail, 2018c). The research on autonomy is limited to theoretical knowledge (Little et al., 2003) that is the reason application of autonomy is not visible and the majority of the students rely solely on their teachers (Yasmin. $\&$ Sohail, 2018), there is more research needed on the learner autonomy in undergraduate and postgraduate levels in order to compare the results in various contexts (Fotiadou et al., 2017). There is less literature in learner autonomy and more research can help to determine the learner development and differences in autonomous language teaching ( $\mathrm{Ou}$ Chuying, 2017). According to Nyinondi et al. (2017), in the past, more research focused on language teaching methods and learning styles. Teachers' competence level, learner autonomy, new teaching strategies and learning assessment in language teaching are the areas that required research and to fill the literature gap (Manan, David \& Dumanig 2015). Since the higher education is playing a key role in providing professionals and educators to contribute to the economy of the country and their skill development is of great importance and this study aims at exploring the teaching and learning of language with reference to communicative competence and learner autonomy development will highlight the main issues and offer recommendations in order to improve the situation in higher education institutions to meet the expectations of academic and corporate sectors.

\section{Research Objectives}

The primary objective of this study is to highlight the main issues which hinder the communicative ability and learner autonomy skill development of the students in the English language teaching and learning context at tertiary level in Pakistan and recommend plausible solutions to overcome them in order to develop the students' learner autonomy and communicative competence at tertiary level in Pakistan.

\section{Significance of the Study}

The education system in Pakistan is fraught with many challenges and English is taught from grade one to the undergraduate programmes but the language proficiency of the students in Pakistan is very low. Students largely depend on their teachers for learning input. Selfdirectedness and independence are the main focus of education at higher education level in all over the world and the Pakistani youth also need the communication skills and self-regulation in order to meet the ever-increasing demands of their professions. The main aim of education is to prepare the learners for future responsibilities. Students' ability in English is of high significance and their autonomy in language learning is equally important in English as a medium of instruction in the research based higher education. The outcome of this study will help the teachers, trainers, policy makers and the learner to understand and devise pedagogical practices to improve communicative competence and learner autonomy of the students at tertiary level.

\section{Methodology}

This study has applied the literature review and situational analysis qualitative approach to collect and analyse the key factors affecting students learning of English language in the higher education institutions in Pakistan. The study is based on the reviews and synthesis of past research studies that focus on the pedagogical practices and problems in the context of language teaching and learning particularly in Pakistan and other countries of the world where English is taught in EFL context. This study is within the qualitative paradigm and used document analysis as research methodology (Bowen, 2009). Situation analysis is combined with organized review and thematic evaluation to determine the factors affecting the students' 
communication and learner autonomy in the higher education in Pakistan. The entire process was involved reading and analysis to reach the themes and categorize those accordingly (Fereday \& Muir-Cochrane, 2006). In this study papers for critical analysis are reviewed from year 2010 to 2018.

\section{Critical Review and Thematic Analysis}

The review of the papers revealed the main themes; gap in skill development, low proficiency, improper evaluation and problematic pedagogy in English language learning at higher education institutions. Communication ability in English language is highly desirable by the teachers and the students and due to the absence of an evaluation system it is not possible to be more focused and moreover the socio-economic conditions are hindering the skill development of the EFL learners in Pakistan. Moreover; the Pakistani education system has two vivid strands; Urdu medium and English medium (Albahri, Yang \& Moustakim, 2018). The private institutions are considered important for their focus on learners' communication ability in English (Bland 2015, P. 23). Private institutions offer more quality education as compared to the public institutions. The privately-owned institutions have well maintained classrooms with state-of-the-art equipment to teach language and moreover; the students in these institutions also have at home support to learn English privately. This makes them distinguished in terms of language learning proficiency (Fenton-Smith, Humphreys \& Walkinshaw, 2017). The majority of students in public run institution suffers more and lack in English proficiency due to the traditional teaching methods. Following is the detail of the thematic analysis and findings of this study conducted in English as Foreign Language context with relation to challenges in development of communicative competence and learner autonomy.

\section{Lack of Focus on Communicative Competence and Learner Autonomy}

Increasing impact of globalisation has made English a lingua franca and thus it has earned high regards for higher education, employability, and social status. It becomes critical to make sure the students at the university level are achieving the desired level of competence and autonomy in English language learning. In order to become self-driven, independent to deal with personal and interpersonal communication needs and carry out their roles abroad and at home in future as leaders, managers, teachers and entrepreneurs (Dar \& Khan, 2015; Sadia et al., 2018; Yasmin \& Sohail, 2018). According to the National Education Framework findings by Ministry of Federal Education and Professional Training Pakistan MFEPTP (2018), the students have inadequate learning outcomes in English at tertiary level education in Pakistan and there is a gap between the academic and the corporate sector regarding the competencybased needs of the undergraduates. In another report by MFEPTP (2017) Pakistan is scrambling to achieve its educational targets in students learning outcomes in terms of skill development. Pakistani youths need higher-order cognitive and communication skills essential to thrive in the highly competitive local and global economy. National Qualification Frameworks of Pakistan (NQF, 2015) emphasizes that students of undergraduate programmes lack in autonomy to handle complex problems independently and should be in possession of effective communication skills to present ideas and knowledge to a variety of audience.

\section{Low Language Proficiency among Pakistani EFL Learners}

Pakistani students' language proficiency level is below as compared to the regional countries in Asia. According to the EF English Proficiency Index (2018), Pakistan ranks $50^{\text {th }}$ out of $86^{\text {th }}$ countries in the region and $12^{\text {th }}$ out of $21^{\text {st }}$ countries in Asia. The British Council (2015) reports that there is no systematic approach to teach language at the university level, which hinders the progress of the students and they have little improvement in language learning, and the teachers' proficiency level is open to discussion in terms of knowledge and competency. 
Traditional language teaching methods are still dominant with text-based activities at tertiary level teaching. British Council report (2015) recommends a further study to fill the gap and verify the statistics to determine the progress in developing communicative competence among the university students in Pakistan.

A large number of students are passing out from the universities and they lack in the basic skills needed by their professions and potential employers (Employer Skill Survey, 2013). According to the Bureau of statistics division of Pakistan report published in the daily Dawn newspaper on 18 March 2018, more than 500000 graduates are unemployed in the country. Unemployment is the result of the economic condition, lack of communication and selfmanagement skills which are highly expected by the employers from the graduates in Pakistan (Abbasi, 2018; Saeed \& Rashidi, 2017). As per Federal Public Service Commission of Pakistan (FPSC) report publish in the daily Dawn on $6^{\text {th }}$ December, 2016, 92\% of the graduate and postgraduate level students were failed in English in the competitive examination for public service in Pakistan and all of the students were from top universities of Pakistan. The failure of students in such a large number in the highly competitive examination shows all is not well with the English language learning in Pakistani universities.

\section{Lack of Evaluation System in EFL Context}

Shamim (2017) observes that there is a need for systematic evaluation and discussion about the need for English in Pakistan. She further reiterated that education system and the teaching methods should be reviewed which mainly focus on examination-based contents, and provide no opportunities to the students to develop their literacy skills and use language effectively in or outside the classrooms. Hameed and Tahir (2016) assert that teaching beliefs, approach and syllabus are the key elements in language teaching and teachers should set high objectives to meet the demanding needs of the learners. Assessment of language learning is a key element and evaluation system in the Pakistani institutions is imperfect and there are numerous factors involved (Ahmad \& Malik, 2011), and these factors are external that include; context and teaching methods and acknowledging achievement whereas internal is; beliefs, motivation, personal ability and attitude. Research studies have shown that failure rate is high in school, colleges and universities where students are unable to achieve their academic objectives as they lack in proficiency in English (Khattak, 2012)

\section{High Social Status of English and Problematic Pedagogy}

In Pakistani society, English language learning is symbolized with status and power and it is a means to move in the elite class, a skill for employability and an important part of a graduate's personality. The English language is an integral part of the Pakistani education system (Ahmad \& Rao, 2012) and a key to succeeding socially and academically (Muhammad, 2011). Despite the academic, social and historical significance of English in Pakistan, the students have problems with language learning and this affects their academic capabilities (Dreyfus et al.,.2016). The interactive nature of the language is in favour that teachers should integrate form and function together in the classrooms to develop the communicative competence of the learners (Svignon, 2017). Language is perceived as a cognitive action of individuals but it is a social venture, jointly constructed by practice and participation in the classroom activities. According to Rasheed et al. (2017) to involve the students in this learning enterprise teachers should play their role (Khan, 2016). The way the English language teachers materialize their theory of teaching is an area that should be explored to measure the learning outcomes and find what support they offer to students to improve the situation of language learning in Pakistan (Raza, 2015; Anbreen, 2015; Yasmin \& Sohail, 2018). 


\section{Opportunities to promote competence and Autonomy in EFL context in Pakistan}

The present study planned to depict the idea of student independence and competence in language learning and this has been clarified from various viewpoints.. Aside from other critical issues in English language pedagogy; competence and autonomy are particularly essential and required more attention. This is because of the novel changes in language learning in most part of the world, for example student focused educational modules, the activities, students' involvement, the Project-based learning and student based training which put students as individual into the center of language learning process. Student focused methodologies have reshaped the jobs of the educators and students, mostly their capacities and expertise. The language learners nowadays have assumed more noteworthy liability of their learning. Thus, autonomy and competence development have turned out to be conspicuous topics in language training. Following are suggestions to improve the EFL context to develop autonomy and communicative competence.

- One of the essential methods for helping students gain autonomy is to show learning systems. "How to learn" on your own. In order to furnish the students with a learning situation in which they can learn in an independent way, the students ought to get technique preparing.

- As such, the teachers should prepare students about how to create and utilize selfdevised strategies techniques for their learning. What's more, the teachers should introduce preparing exercises which expect to build students' information of helpful approaches to learn and build up the techniques they require (Hedge, 2000).

- A noteworthy component of making an independent English language classroom is the utilization of portfolios.

- The jobs of teachers in creating learner autonomy are significantly more order of the reason. They have key place in making a self-sufficient language classroom for students.

- Student independence in encouraging English as a foreign language holds a focal place in the field. To begin with, students are associated with their learning; they are very dynamic; so their learning is progressively effective.

- Cognitive theories of motivation offer valuable schemas for understanding and, in some cases, changing the interaction patterns of teachers and students. Teachers can examine their own beliefs about students learning, and why do students succeed or fail at the tasks that the teachers assign them? Based on these analyses, teachers can make changes, if necessary, in the tasks they assign, the learning environments they create, and their verbal interactions with their students.

All together for these suggestions to be tried, well suited activities should be taken from the very beginning level. The communicative activities may basically incorporate in EFL educational programs and the task-based exercises that empower students to get engaged with the learning procedure all the more successfully. Second, EFL teachers ought to attempt continuous expert improvement to invigorate their learning and keep them side by side with current patterns in the field. The stuffed classes is also thought to be one of the biggest hindrances that upset the execution of communicative teaching in EFL college setting. To enhance students' interest classroom setting should be given priority, making it an all the more engaging and pleasing condition for the execution of student-based exercises. This incorporates furnishing classrooms with adequate innovation improved apparatuses, for example; communicative activities, access to resources, multimedia and dynamic tables setting for group exercises. Moreover, teachers training and use of innovative technology can bring fruitful Copyright (C) GLOBAL ACADEMIC EXCELLENCE (M) SDN BHD - All rights reserved 
results and help develop students their skill level in English language so they can independently and confidently handle their communication needs at tertiary level and later in professional careers. From the literature review and situational analysis, it can be concluded that the language teaching at tertiary level in Pakistan needed to be explored in order to pave the path for the change in language teaching practices and develop communicative competence and learner autonomy of the students.

\section{Conclusion}

The primary objective of the study was to determine the main factors undermining the development of students' communicative competence and learner autonomy at higher education level and this has been achieved by identifying the main affecting factors. The critical analysis of the past studies has shown that students have hard desires to have strong communication skills in the English language due to its social and professional significance. The main factors identified are; wide gap in skill demands and skill development, students have low proficiency, language evaluation system is outdated, and traditional pedagogy are the main reasons hindering skill development in the Pakistani EFL context. Students' skills can be promoted in competence and autonomy areas through providing them with interpersonal skill promotion and providing them with physical space in learning the target language.

For the development of any country young professionals play a key role and their skill development should be the priority of the educational institutions. The findings of this research show that there is gap in the students' communication and autonomous learning development. The mixing of Urdu and English instructions confuses the students, low proficiency of the teachers, inadequate evaluation system and traditional pedagogical practices are the main reasons which hinder the progress of the students in English language learning. The role of language proficiency in academic achievement and its social significance for the students at local and global level demands contingency measures. Moreover; the students are expected to be responsible for their learning and be self-directed. The need of learners autonomy and language competence at higher education level require further in depth study to determine the communicative competence and learner autonomy level of the teachers and the students and the results will help to make decision at policy making level and will also facilitate the teachers and the trainers to design the syllabus accordingly in higher education institutions in Pakistan.

References

Abbasi, F., Ali, A. and Bibi, N. (2018), "Analysis of skill gap for business graduates: managerial perspective from banking industry", Education + Training, Vol. 60 No. 4, pp. 354-367. https://doi.org/10.1108/ET-08-2017-0120

Ahmad, S. \& Rao, Congman. (2012)- Inconsistencies In English Language Teaching In Pakistan: A Comparison between Public and Private Institutions European journal of business management https://www.academia.edu/4025942/Inconsistencies_in_English_Language_Teaching _in_Pakistan_A_Comparison_between_Public_and_Private_Institutions

Ahmad, S. \& Rao, Congman. (2013). Applying Communicative Approach in Teaching English as a Foreign Language: a Case Study of Pakistan Institute of International \& Comparative Education, Northeast Normal University, China Congman Rao Faculty of Education, Northeast Normal University, China ISSN: 1697-7467 Porta Linguarum 20, junio 2013 pp. 187-203

Ahmad, S., Malik, S. (2011). Examination scheme at secondary school level in Pakistan: Composite vs. split. Canadian Social Science, 7(1), 130-139. 
Akhtar N. (2106). Teachers' and Students' perceptions of Autonomy using Inquiry-Based Learning in Initial the Teacher Education Journal of Research and Reflections in Education June 2016, Vol. 10, No.1, pp 1-15 http://www.ue.edu.pk/jrre

Akram, M \& Mahmood, A. (2007). -Pakistan The status and teaching of English in Pakistan. Language in India, (7). Retrieved from http://www.languageinindia.com/ dec2007/englishinpakistan.pdf

Albahri, M. A., Yang, P., \& Moustakim, M. (2018). Saudi Arabian tertiary teachers' and learners' attitude towards the "Communicative Language Teaching (CLT)". International Journal of Information and Education Technology, 8(4), 317- 321.

Anbreen (2015). The Influence of English Second Language Learning On Pakistani University Students' Identity

Bachman, L., \& Palmer, A. (1981). A multitrait-multimethod investigation into the construct validity of six tests of speaking and reading. In A. Palmer (Ed.), The construct validation of tests of communicative competence (pp. 149-165). Alexandria, Virginia: TESOL.

Benson, P. (2011). Teaching and Researching Autonomy. London: Routledge.

Bland, J. (Ed.). (2015). Teaching English to young learners: critical issues in language teaching with 3-12-year olds. Bloomsbury Publishing.

Block, D., \& Cameron, D. (2002). Globalization and language teaching. London and New York: Routledge

Boud, D. (1988). Moving Towards Autonomy. In D. Boud (Ed.), Developing Student Autonomy in Learning. London: Kogan Page Ltd, pp. 17-39.

Bowen, A. G. (2009). Document analysis as a qualitative research method. Qualitative

British Council Report, 2015: "English Language in Pakistan Higher education report 2015 https://www.britishcouncil.pk/sites/default/files/english_language_in_pakistan_higher _education_-_2015.pdf

Çakici, D. (2015). Autonomy in Language Teaching and Learning Process. İnönü University Journal of the Faculty of Education. 16(1), 31-42.

Canale, M. \& Swain, M. (1980). Theoretical bases of communicative approaches to second language teaching and testing. Applied Linguistics, 1, 1-47.

Dar, M. F., \& Khan, I. (2015). Writing anxiety among public and private sectors Pakistani

Dreyfus, S., Humphrey, S., Mahboob, A. \& Martin, J. R. (2016). Genre pedagogy in higher education: The SLATE project. Basingstoke: Palgrave Macmillan.

Employer Skill Survey. (2013). https://www.gov.uk/government/publications/ukcesemployer-skills-survey-2013

Fenton-Smith, B., Humphreys, P., \& Walkinshaw, I. (2017). English medium instruction in higher education in Asia-Pacific. Springer International Publishing.

Fereday, J. \& Muir-Cochrane, E. (2006). Demonstrating rigor using thematic analysis: A

Fotiadou Aggeliki et al. (2017).

Learner Autonomy As A Factor Of The Learning Process In Distance Education Euro pean Journal Of Open, Distance And ELearning - Vol. $20 /$ No. 195 Issn 10275207 (C) 2017 Eden

FPSC, 2015: Federal Public Service Commission of Pakistan FPSC report published in The Daily Dawn on December 06, 2016) https://www.dawn.com/news/1300724

Halliday, A. (1994) The house of TESEP and the communicative approach:the special needs of state English language education. ELT Journal, 48(1), pp.3-11.

Hameed and Tahir (2016) Comparative Study Of Teaching Strategies In The Higher Education System Of Punjab And Khyber Pakhtunkhwa Pakistan. Gomal University Journal of Research [GUJR] Vol 32 Issue 2 DEC 2016 ISSN: 1019-8180: hybrid approach of inductive and deductive coding and theme development. 
Hymes, D. (1971). On communicative competence. Philadelphia, PA: University of Pennsylvania Press.

International Journal of Qualitative Methods, 5(1), 80-92.

Johnson. (2009). An Educational Psychology Success Story: Social Interdependence Theory and Cooperative Learning https://doi.org/10.3102\%2F0013189X09339057

Khan, I.A. (2011). Challenges of teaching/learning English and management. Global Journal of Human Social Sciences. Vol.11 No.8 pp.68-80.

Khan. (2016). Obstacles in Learning English as a Second Language among Intermediate Students of Districts Mianwali and Bhakkar, Pakistan Open Journal of Social Sciences, 2016, 4, 154-162 Published Online February 2016 in SciRes. http://www.scirp.org/journal/jss http://dx.doi.org/10.4236/jss.2016.42021

Khattak, S. G. (2012). Assessment in schools in Pakistan.SA-e DUC Journal 9(2).

Knapper, C. (1988). Technology and Lifelong Learning. In D. Boud (Ed.), Developing Student Autonomy in Learning. London: Kogan Page Ltd, pp. 91-106.

Little, D. (1996). Autonomy in language learning: Some theoretical and practical considerations. InA. Swarbrick (Ed.), Teaching Modern Languages. London: Routledge, pp. 81-87.

Littlewood, W. (1999). Defining and developing autonomy in East Asian contexts. Applied Linguistics. 20(1), pp. 71-94.

Manan, David, and Dumanig. (2015). English Language Teaching in Pakistan: Language Policies, Delusions and Solutions Chapter ·from book English Language Education Policy in Asia (pp.219-244 December 2015 with2,600 Reads Publisher: $1^{\text {st }}$ DOI: 10.1007/978-3-319-22464-0_10 Publisher: English Language Teaching in Pakistan: Language Policies, Delusions and Solutions Publisher: 1571-5361 Publisher: Springer, Editors: Robert Kirkpatrick

MFEPTP. (2018). Ministry of Federal Eduation and professional training Islamabad http://aserpakistan.org/document/2018/National_Eductaion_Policy_Framework_2018 _Final.pdf

Muhammad, S. (2011). L2 reading instruction and reading beliefs of English teachers in public sector universities in Pakistan (Unpublished M.A. Thesis). Northern Arizona University, Flagstaff, USA.

Muhammad, Z. (2016). Pakistani Government Secondary Schools Students' Attitudes towards Communicative Language Teaching and Grammar Translation in Quetta, Balochistan English Language Teaching; Vol. 9, No. 3; 2016 ISSN 1916-4742 E-ISSN 1916-4750 Published by Canadian Center of Science and Education

NQF., (2015) National Qualification Framework. Pakistanhttp://hec.gov.pk/english/services/universities /pqf/Pages/default.aspx

Nyinondi, O. S., Mhandeni, A. S., \& Mohamed, H. I. (2017): The use of communicative language teaching approach in the teaching of communication skills courses in Tanzanian

OECD Organisation for Economic Co-Operation and Development. (2007-2016). Qualifications Systems: Bridges to Lifelong Learning. Education and Training Policy. Paris: OECD.

Ou, Chuying.(2017). A Review on Language Learner Autonomy Research in China (20062016): Based on 12 Key Domestic Journals English Language Teaching; Vol. 10, No. 11; 2017 ISSN 1916-4742 E-ISSN 1916-4750 Published by Canadian Center of Science and Education

Rasheed et al. (2017). Challenges of Teaching English Language in a Multilingual Setting: An Investigation at Government Girls Secondary Schools of Quetta, Baluchistan, Pakistan 
International Journal of English Linguistics; Vol. 7, No. 4; 2017 ISSN 1923-869X EISSN 1923-8703 Published by Canadian Center of Science and Education

Rawan, H. H. (2016). Developing Learner Autonomy in Vocabulary Learning in the classroom: How and Why can it be Fostered? Procedia - Social and Behavioral Sciences, 232, 784791. https://doi.org/10.1016/j.sbspro.2016.10.106

Raza, (2015). Language Attitude and English Language Learning in Pakistan https://www.researchgate.net/publication/322445848

Research Journal, 9 (2), 27-40..

Sadia Asif, Rahat Bashir \& Shabana Zafar. (2018). What Are the Factors Affecting the Use of English Language English-only Classrooms: Student's Perspectives in Pakistan. English Language Teaching; Vol. 11, No. 6; 2018 ISSN 1916-4742 E-ISSN 1916-4750 Published by Canadian Center of Science and Education

Saeed and Rashidi, 2017: Essential Employability Skills For Marketing Careers: Gap Analysis Of Education AndProfessionhttp://Journals.Iobmresearch.Com/Index.Php/Pbr/Article/Viewfile/144 $8 / 258$

Sarfraz et al. (2015) -Pakistan Teachers' and students' perceptions of the communicative language teaching methodology in the CALL environment: A case study Procedia Social and Behavioral Sciences 199 (2015 ) 730 - 736

Savignon, S. J. (2007) Communicative Language Teaching: Linguistic theory and Classroom Practice, The McGraw Hill Second Language Professional Series

Savignon, S. J. (2017). Communicative Competence. The TESOL Encyclopedia of English Language Teaching,1-7. doi:10.1002/9781118784235.eelt0047

Shamim, F. (2009). English as the language for development in Pakistan: Issues, challenges and possible solutions. In H. Coleman (Ed.), Dreams and realities: Developing countries and the English language (pp. 291-309).

Suarta et al.,2017: Employability skills required by the $21^{\text {st }}$ century workplace: a literature review of labour market demand 1st International Conference on Technology and Vocational Teachers (ICTVT 2017)

Yaqoob, H. M. A. (2015). Constraints Faced by Teachers in Conducting CLT Based Activities at Secondary School Certificate (SSC) Level in Rural Area of Pakistan. Educational Research International Volume 4(2), 109-118

Yasmin, M. \& Sohail, A. (2018). Learner Autonomy: Pakistani English Teachers' Beliefs Bulletin of Education and Research August 2018, Vol. 40, No. 2 pp. 179-194 http://pu.edu.pk/images/journal/ier/PDF-FILES/13_40_2_18.pdf5: 1501888 https://doi.org/10.1080/2331186X.2018.1501888

Yasmin, M. \& Sohail, A. (2018). Socio-cultural barriers in promoting learner autonomy in Pakistani universities: English teachers' beliefs. Cogent Education, 5(1) 1-12. https://doi.org/10.1080/2331186X.2018.1501888.

Yasmin, M., \& Sohail, A. (2018). A creative alliance between learner autonomy and English language learning: Pakistani university teachers' beliefs. Creativity Studies, 11(1), 1-9. https://doi.org/10.3846/23450479.2017.1406874.

Yasmin, M., \& Sohail, A. (2018). Realizing learner autonomy in Pakistan: EFL teachers' beliefs about their practices. International Journal of English Linguistics; 8(2), 153 162. https://doi.org/10.5539/ijel.v8n2p153. 